\title{
Toleransi Berbagai Varietas Tebu terhadap Penggenangan pada Fase Bibit Berdasarkan Karakter Morfologi dan Anatomi
}

\author{
Tolerance of Sugarcane Varieties toward Waterlogging at Seedling \\ Stage based on Morphological Characteristics and Anatomy
}

\author{
Sholeh Avivi*, Anang Syamsunihar, Sigit Soeparjono, dan Muhammad Chozin \\ Jurusan Agroteknologi, Fakultas Pertanian, Universitas Jember \\ J1. Kalimantan 23 Jember 68121, Indonesia
}

Diterima 4 April 2017/Disetujui 17 Februari 2018

\begin{abstract}
Identification of Indonesia sugarcane varieties tolerant to waterlogging has not been done extensively. Information on varieties tolerant to waterlogging is required for seedling establishment in waterlogged areas. The purpose of this research was to identify the sugarcane varieties responses to several duration levels of waterlogging at seedling stage. The planting materials used were collection of Sugar Factory Semboro including VMC 76-16, BL, PS 862, PS 864, and PS 881. This research was arranged in randomized complete block design (RCBD) with two factors and three replications. The first factor was 5 varieties; the second factor was waterlogging treatment with four levels, i.e. without waterlogging, 2, 4, and 6 weeks of waterlogging in the bucket. The results showed different level of tolerance to water logging among the varities. PS 881 and VMC 76-16 varieties were the most tolerant to waterlogging supported by its ability to maintain plant height, root volume, root and shoot dry weight after been waterlogged for 6 weeks. These varieties were also able to establish aerenchyme tissue and increased the stomatal density. PS 862 was the least tolerant variety to waterlogging.
\end{abstract}

Keywords: aerenchyme, morphology, stomatal density, waterlogging, water stress

\section{ABSTRAK}

Identifikasi varietas tebu Indonesia yang toleran genangan belum banyak dilakukan. Informasi varietas toleran genangan sangat diperlukan untuk penyediaan bibit untuk lahan tergenang. Penelitian ini bertujuan untuk mengidentifikasi respon beberapa varietas terhadap cekaman genangan pada fase pembibitan. Bibit yang digunakan berasal dari koleksi Pabrik Gula Semboro terdiri atas VMC 76-16, BL, PS 862, PS 864, dan PS 881. Penelitian menggunakan Rancangan Acak Kelompok dengan 2 faktor dan 3 ulangan. Faktor pertama adalah varietas terdiri atas 5 taraf dan faktor kedua adalah lamanya penggenangan terdiri atas 4 taraf yaitu: kontrol tanpa penggenangan, dan di genangi selama 2, 4, dan 6 minggu. Hasil penelitian menunjukkan bahwa terdapat perbedaan toleransi antara varietas yang diuji. Varietas paling toleran adalah PS 881 diikuti oleh varietas VMC 76-16 yang ditunjukkan dengan karakter morfologi tinggi tanaman, volume akar, berat kering akar dan tajuk dan karakter anatomi berupa terbentuknya jaringan aerenkim pada akar adventiv dan meningkatnya kerapatan stomata. Varietas paling peka genangan adalah PS 862.

Kata kunci: aerenkim, cekaman air, kerapatan stomata, morfologi, penggenangan

\section{PENDAHULUAN}

Lahan pertanaman tebu di Indonesia pada tahun 2015 diperkirakan sebesar 487.095 hektar dengan produksi gula hablur total sebesar 2.728.393 ton (Direktorat Jenderal Perkebunan, 2014). Produksi sebesar itu masih belum dapat memenuhi kebutuhan dalam negeri, sehingga sangat dibutuhkan peningkatan produksi yang dapat dilakukan dengan ektensifikasi lahan tebu. Lahan-lahan

\footnotetext{
* Penulis untuk korespondensi. e-mail: savivi.faperta@unej.ac.id
}

tebu yang tersedia memiliki potensi terkena banjir, sebagai akibat perubahan iklim global yang juga mengakibatkan sulitnya prediksi banjir di lahan. Tidak hanya terjadi pada pertanaman tebu, Yullianida et al. (2014) menyatakan bahwa anomali iklim berdampak juga terhadap sulitnya memprediksi terjadinya banjir di lahan pertanaman padi. Zhao and Li (2015) menyatakan bahwa pertanaman tebu yang terkena banjir dapat menurun produksinya. Penurunan produksi tebu akibat terkena banjir di Indonesia belum ada yang melaporkan. Laporan penurunan produksi tebu akibat banjir terjadi di Florida pada tahun 2003 dan 2005, dimana pada lahan yang kebanjiran menghasilkan rata-rata 7.8 ton 
sukrosa ha ${ }^{-1}$ menurun sebesar $37 \%$ dibandingkan dengan lahan yang tidak terkena banjir yang menghasilkan 12.3 ton sukrosa ha-1 (Gilbert et al., 2008). Lahan marginal tergenang sangat berpotensi untuk perluasan lahan pertanaman tebu. Sebagai contoh petani di Florida, menanam tebu di dataran rendah yang sering terkena banjir dengan luasan hingga 280,000 ha (Gilbert et al., 2008).

Saat ini genangan air dan banjir dianggap sebagai salah satu kejadian alam yang berbahaya bagi lahan pertanian, terutama di negara-negara yang memiliki dataran rendah luas (Verhoeven dan Setter, 2010). Banjir yang bersifat sementara atau terus menerus adalah salah satu cekaman abiotik utama yang menentukan reaksi adaptif tanaman dan produktivitas pertanian (Fan et al., 2015). Menurut Gilbert et al. (2008) jika tebu ditanam di lahan tercekam genangan; produktivitas akan menurun yang tergantung pada varietas tebu yang digunakan, fase pertumbuhan tanaman, lamanya tanaman tergenang, tekstur tanah, dan kehadiran penyakit. Cekaman genangan pada tanaman akan menimbulkan respon yang berbeda tergantung pada varietas tanaman yang digunakan dan tingkat cekaman (Pucciariello dan Perata, 2013). Varietas yang peka akan merespon cekaman genangan dengan menghentikan pertumbuhan hingga kematian sedangkan varietas toleran akan membentuk jaringan aerenkim dan memacu pertumbuhan untuk menghindari stress (Mickelbart et al., 2015). Varietas tebu Indonesia yang toleran genangan seperti PS 881 and PS 862 merespon cekaman genangan dengan menurunkan klorofil dan kandungan protein serta meningkatkan jumlah stomata, densitas akar, dan kandungan brix (Avivi et al., 2016).

Varietas unggul tebu toleran genangan di Indonesia perlu segera disediakan untuk mengantisipasi terjadinya banjir pada lahan tebu yang asalnya tidak terpapar banjir dan untuk tujuan ekstensifikasi lahan tebu pada lahan marginal yang punya potensi tergenang. Permasalahannya varietas tebu toleran genangan spesifik lokal Indonesia belum tersedia. Penelitian ini berusaha menjawab permasalahan tersebut yaitu menyeleksi varietas tebu unggul toleran genangan.

\section{BAHAN DAN METODE}

Penelitian ini dilaksanakan di Desa Karangharjo, Kecamatan Silo, Kabupaten Jember selama 4 bulan pada bulan Januari sampai April 2014. Penelitian menggunakan rancangan acak kelompok (RAK) 2 faktor dengan 3 ulangan. Faktor pertama adalah perlakuan genangan dengan 4 taraf yaitu tanpa penggenangan, 2, 4, dan 6 minggu penggenangan dalam ember (Gambar 1). Perlakuan kedua adalah varietas dengan 5 taraf yaitu: VMC 76-16, BL, PS 862, PS 864, dan PS 881. Bibit yang digunakan berasal dari planlet hasil kultur jaringan (rata-rata tinggi tanaman 30 $\mathrm{cm}$ dengan diameter $0.8 \mathrm{~cm}$ ) yang ditanam dan dipelihara sampai berumur 8 minggu, kemudian diberi perlakuan penggenangan sesuai perlakuan (tinggi muka air dijaga 15 $\mathrm{cm}$ di bawah permukaan tanah). Pemeliharaan tanaman tebu dilakukan dengan cara menyiram tebu setiap hari, menyiangi gulma yang tumbuh, mengendalikan hama penyakit, serta menyulam tanaman yang mati.
Pengamatan secara visual dilakukan pada jaringan aerenkim pada akar adventif. Pembuatan preparat akar adventiv dengan metode irisan embeding dengan parafin dan pewarnaan menggunakan Safranin 1\%. Sampel akar adventive diambil pada waktu satu hari setelah perlakuan penggenangan terakhir. Pengamatan jaringan dilakukan dalam preparat kaca di bawah mikroskop perbesaran 400x.

Pengamatan karakter agronomis terdiri atas pengukuran tinggi tanaman, jumlah daun, jumlah daun menguning, jumlah anakan, berat kering akar, berat kering tajuk, dan kerapatan stomata. Kerapatan stomata diamati dengan cara mengambil sampel dengan mengoleskan kuteks pada bagian bawah daun. Setelah kuteks mengering selotip ditempelkan pada bagian bawah daun yang telah diolesi kuteks, kemudian selotip ditarik, disimpan dalam plastik dan ditempelkan pada kaca preparat. Preparat diamati dibawah mikroskop dengan perbesaran 400x. Setiap sampel dihitung kerapatannya dengan rumus: Kerapatan stomata $=$ Jumlah stomata / satuan luas bidang pandang. Data karakter kuantitatif dianalisis menggunakan analisis ragam dan uji lanjut menggunakan uji jarak berganda Duncan (DMRT) dengan taraf $5 \%$.

\section{HASIL DAN PEMBAHASAN}

Beberapa varietas yang diberi perlakuan genangan pada fase pembibitan menunjukkan toleran terhadap penggenangan. Hal ini terlihat pada semua varietas tetap hidup, tumbuh, dan berkembang setelah perlakuan penggenangan selama 6 minggu. Setiap varietas mempunyai respon yang berbeda terhadap karakter-karakter yang diamati.

\section{Tinggi Tanaman}

Pertumbuhan ditandai dengan perubahan yang terjadi dalam kehidupan tanaman dan pertambahan organ tanaman. Parameter pertumbuhan pada penelitian ini digunakan

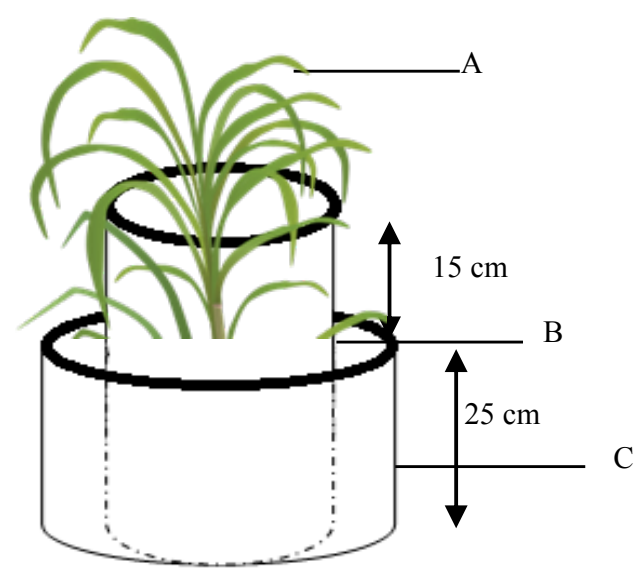

Gambar 1. Skema perlakuan genangan pada pembibitan tebu. Bibit tebu yang di tanam di media tumbuh dalam polibag (A), Polibag tanaman dengan tinggi muka media $15 \mathrm{~cm}$ dari permukaan air (B), Ember yang berisi air, yang dijaga permukaan airnya selalu terisi penuh (C) 
sebagai indikator untuk mengetahui karakteristik ketahanan tanaman terhadap genangan. Varietas menunjukkan perbedaan yang sangat nyata pada tinggi tanaman setelah perlakuan selama 6 minggu. Varietas VMC 76-16 memiliki data tanaman tertinggi dan pada perlakukan 6 minggu penggenangan, tinggi tanaman sama dengan kontrol. Varietas PS 862, PS 864, dan PS 881 menunjukkan nilai tinggi tanaman yang lebih rendah setelah perlakuan penggenangan. Varietas BL setelah perlakuan penggenangan menunjukkan respon lebih tinggi dibandingkan dengan kontrol (Gambar 2).

\section{Jumlah Daun Segar}

Perlakuan lama penggenangan berpengaruh sangat nyata terhadap jumlah daun segar. Gambar 3 menunjukkan bahwa perlakuan kontrol (tanpa penggenangan) menghasilkan jumlah daun segar tertinggi dan semakin lama perlakuan genangan menurunkanjumlah daun segar. Menurut Lee et al. (2014), stres penggenangan juga mengakibatkan penurunan jumlah klorofil daun, meningkatkan jumlah daun menguning dan jumlah daun yang gugur.

\section{Berat Kering Tajuk dan Akar}

Penggenangan air berpengaruh terhadap daya serap akar tanaman terhadap nutrisi dalam tanah (Xiaoming, 2013). Perlakuan lama penggenangan berpengaruh tidak nyata pada berat kering tajuk dan berpengaruh nyata terhadap berat kering akar. Data pada Gambar 4 menunjukkan semakin lama penggenangan cenderung menurunkan berat kering tajuk, kecuali penggenangan selama 6 minggu yang cenderung menghasilkan berat kering tajuk lebih tinggi daripada kontrol (tanpa penggenangan). Berat kering akar semakin meningkat dengan bertambahnya perlakuan genangan. Perlakuan 6 minggu penggenangan menyebabkan nilai berat kering akar tertinggi dan sangat berbeda nyata dengan perlakuan kontrol. Hal ini disebabkan pertumbuhan akar adventive pada tanaman yang tergenang lebih lama lebih pesat dan jumlah cabang akar semakin banyak sehingga berat kering akar meningkat (Gambar 4). Akar adventif dapat menjadi saluran pensuplai oksigen bagi tanaman (Dawood et al., 2008). Akar ini tumbuh mendekati permukaan tanah di bagian atas media tumbuh di mana oksigen tersedia lebih tinggi. Kemampuan tanaman untuk memproduksi akar adventif umumnya berkaitan dengan meningkatnya toleransi tanaman terhadap genangan (Parent et al., 2008).

Varietas yang berbeda memiliki berat kering akar yang berbeda. Varietas yang mempunyai berat kering akar tinggi dapat mengindikasikan varietas yang mempunyai toleransi tinggi terhadap genangan (Ahmed et al., 2008). Respon dari masing-masing varietas berbeda ketika diberi perlakuan genangan khususnya respon pertumbuhan akar adventive. Varietas VMC 76-16, PS 864 dan PS 881 mempunyai berat kering akar yang tidak berbeda nyata, namun ketiganya memiliki berat kering akar yang lebih tinggi dari varietas BL dan PS 862. Sedangkan semua varietas yang di uji memiliki berat kering tajuk yang tidak berbeda nyata (Gambar 6).

Varietas VMC 76-16 mempunyai tinggi tanaman tertinggi dibandingkan dengan varietas lain yang diuji (Gambar 2), yang di ikuti pula oleh tingginya berat kering akar (Gambar 6). Hal ini mengindikasikan bahwa ada pengaruh signifikan antara peningkatan berat kering akar dan tinggi tanaman yang toleran genangan seperti Varietas VMC 76-16. Varietas VMC 76-16 mempunyai karakter adaptasi dan toleransi yang tinggi terhadap genangan. Jika di bandingkan antara Varietas VMC 76-16 dan varietas PS 881, maka varietas VMC 76-16 lebih toleran terhadap cekaman genangan sebab pada varietas VMC 76-16 tingginya berat kering akar di ikuti oleh meningkatnya tinggi tanaman. Dapat disimpulkan tanaman tebu dalam mempertahankan

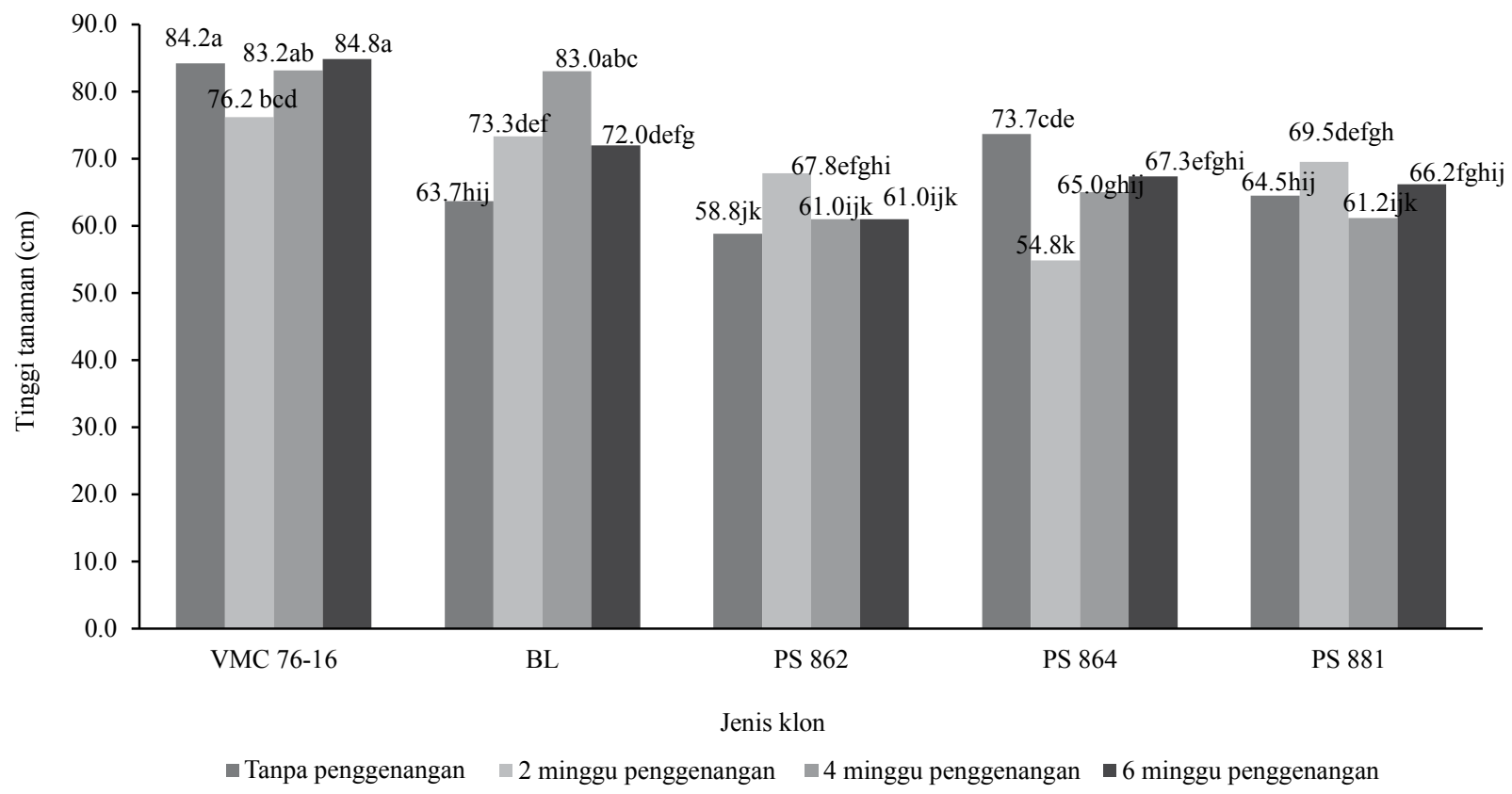

Gambar 2. Pengaruh perlakuan lama penggenangan terhadap tinggi tanaman klon tebu yang diuji 


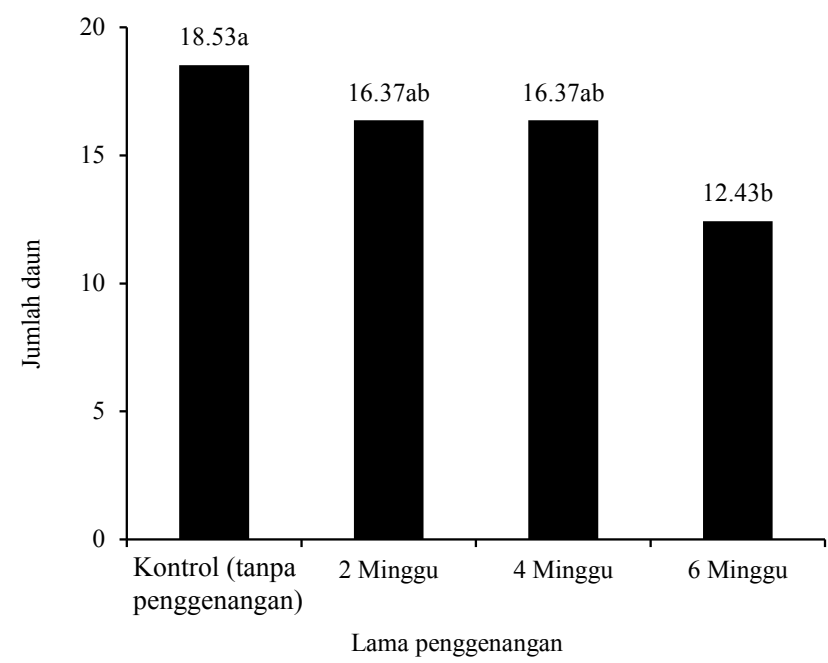

Gambar 3. Pengaruh lama penggenangan terhadap jumlah daun segar tanaman tebu per rumpun

hidupnya menghadapi cekaman genangan adalah dengan cara berdiferensiasi membentuk akar adventif, selanjutnya akar adventif ini akan melakukan serapan hara dengan lebih banyak dan mampu meningkatkan tinggi tanaman. Akar adventif muncul pada buku ruas batang, mulai dari ruas pertama dari permukaan tanah hingga ruas yang kelima dari permukaan tanah (Widyasari et al., 2011).

\section{Jaringan Aerenkim}

Secara kuantitatif respon akar terhadap cekaman genangan dapat diketahui dengan melihat nilai dari berat kering akarnya. Parameter ini didukung dengan adanya data kualitatif secara visual tanaman yaitu adanya jaringan aerenkim pada akar adventif (Widyasari et al., 2011). Pezeshki dan DeLaune (2012) menjelaskan bahwa terbentuknya jaringan aerenkim merupakan respon tanaman terhadap genangan. Jaringan aerenkim berupa jaringan putih berpori yang terbentuk pada hipokotil akar utama, akar adventif, dan akar nodul setelah beberapa waktu dilakukan penggenangan.

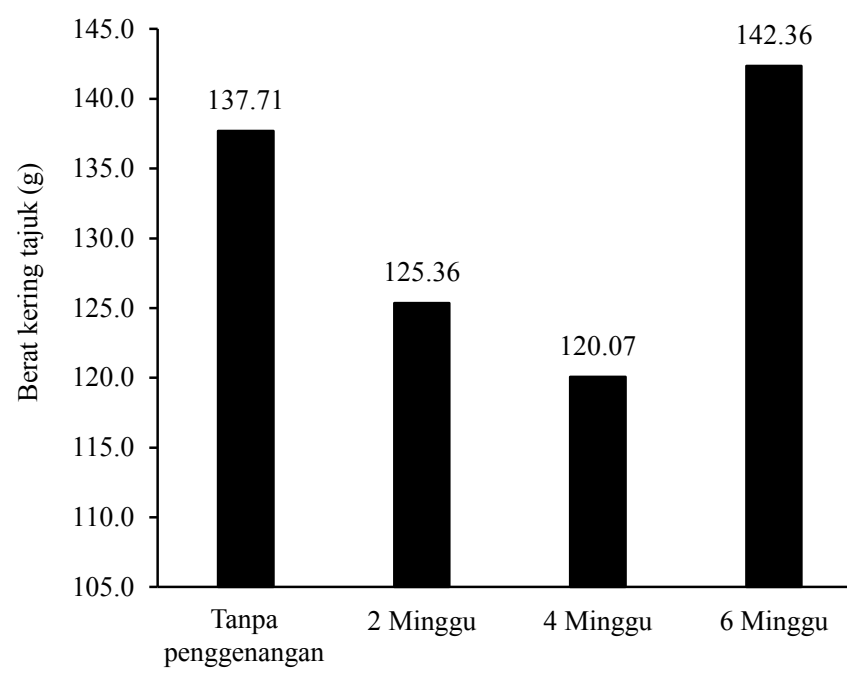

Gambar 4. Pengaruh penggenangan terhadap berat kering tajuk dan akar
Data visual dari Gambar 7 terlihat varietas VMC 7616 menunjukkan adanya jaringan aerenkim yang sempurna dibandingkan dengan varietas-varietas yang lain dengan adanya rongga yang lebih longgar dan lebih merata sehingga jaringan tersebut dapat menjadi fasilitas masuknya oksigen ke dalam tanaman dan menyebabkan proses metabolisme akar tidak terganggu. Haque et al. (2014) menyatakan bahwa tanaman dengan persentase luas aerenkim terbesar menunjukkan ketahanan lebih baik.

Widyasari et al. (2011) menyatakan bahwa varietasvarietas yang memiliki toleransi tinggi mempunyai kerapatan jaringan yang cenderung lebih longgar dan merata. Kenampakan visual jaringan aerenkim tersajikan pada Gambar 7. Varietas BL yang tidak diberi perlakuan genangan aerenkim sel akarnya tersusun lebih rapat dan kecil-kecil sedangkan akar varietas BL yang diberi perlakuan penggenangan selama 6 minggu nampak adanya rongga jaringan aerenkim yang lebih besar. Hal yang sama juga terdapat pada varietas PS 862 dan PS 864. Rongga jaringan aerenkim yang lebih rapat memungkinkan oksigen yang masuk ke dalam tanaman lebih sedikit sehingga pertumbuhannya lebih lambat apabila dalam kondisi tercekam genangan. Pezeshki dan DeLaune (2012) menyatakan bahwa terbentuknya jaringan aerenkim merupakan syarat utama tanaman untuk mempertahankan aktivitas akarnya dalam menyerap unsur hara dan air serta untuk mempertahankan metabolismenya selama dalam keadaan tercekam genangan.

\section{Kerapatan Stomata $\left(\mathrm{mm}^{-2}\right)$}

Varietas PS 881 menunjukkan nilai kerapatan stomata yang tertinggi diantara varietas-varietas yang lain (Tabel 1 dan Gambar 8). Diduga varietas ini memiliki sifat toleransi terhadap cekaman genangan dengan cara meningkatkan kerapatan stomata pada saat stress genangan. Hal ini sesuai dengan yang dilaporkan oleh Widyasari et al. (2011) bahwa varietas yang memiliki sifat toleran genangan memiliki kerapatan stomata tinggi.

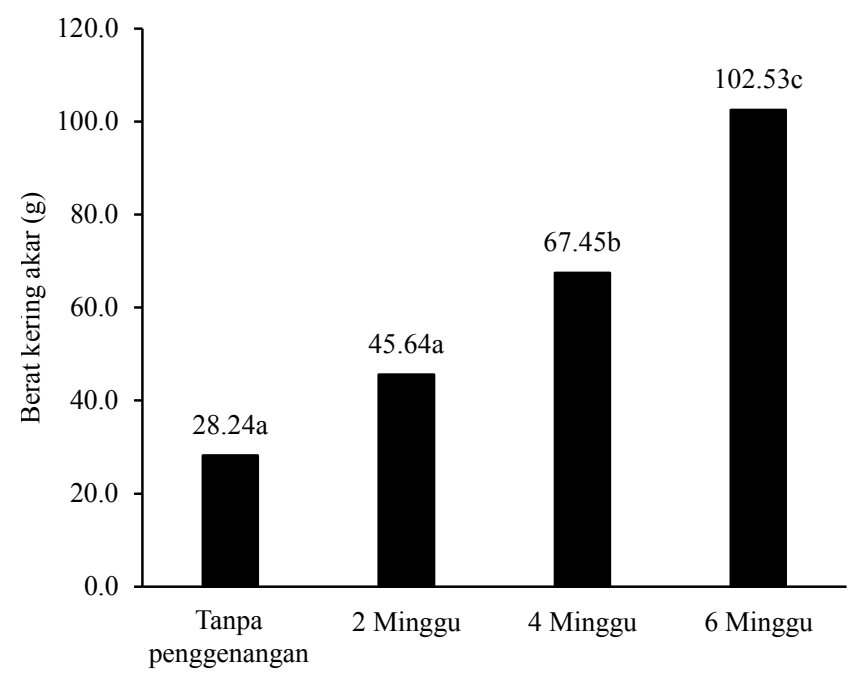




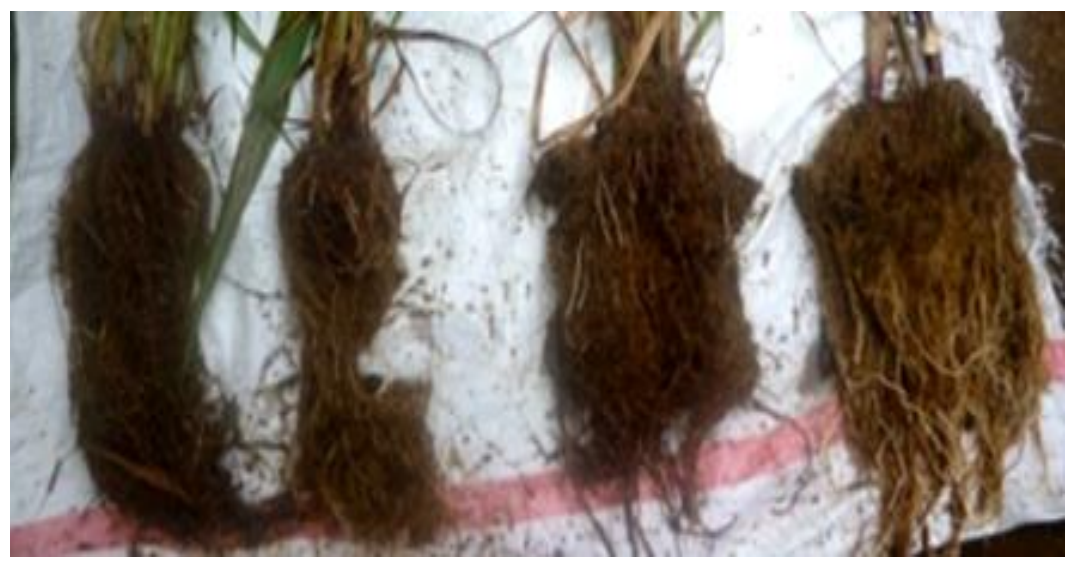

Gambar 5. Penampilan akar tanaman tebu. Berturut-turut dari kiri kekanan: perlakuan tanpa genangan, 2, 4 dan 6 minggu penggenangan
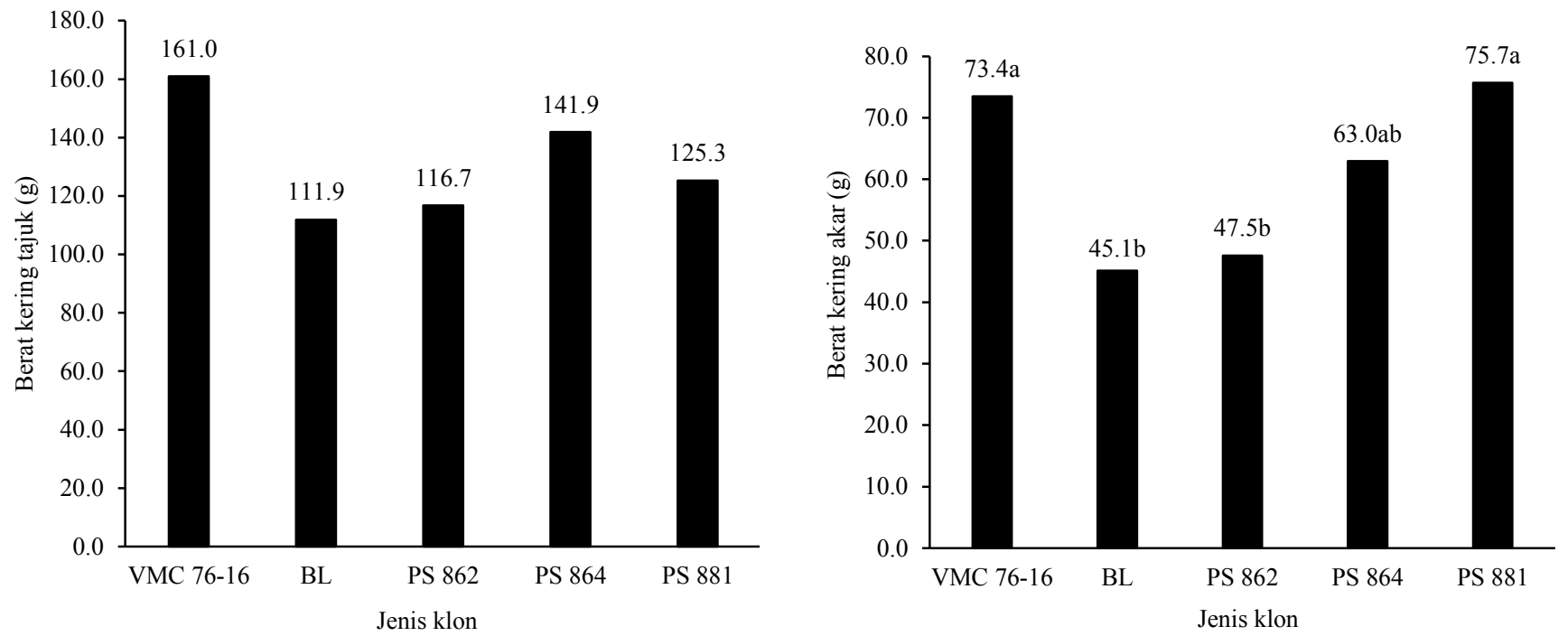

Gambar 6. Berat kering tajuk dan akar pada varietas tebu yang diuji

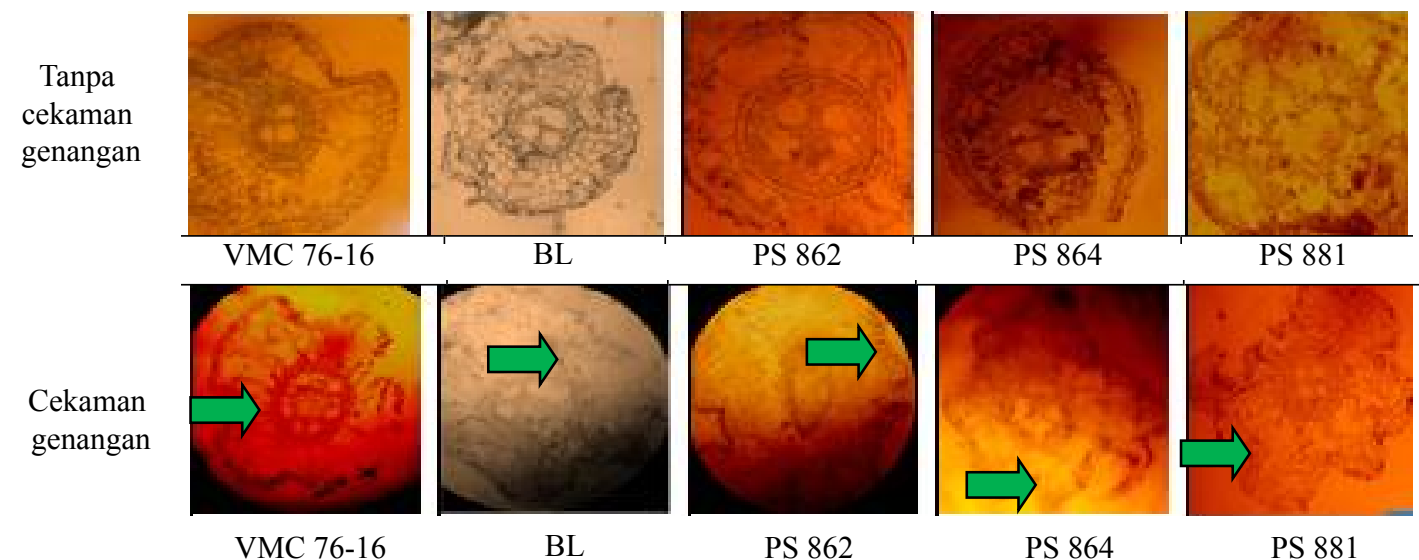

Gambar 7. Jaringan aerenkim pada akar. Tanda panah menunjukkan bentuk dan letak jaringan aerenkim

Pertambahan kerapatan stomata dari sebelum diberi perlakuan genangan dan setelah diberi perlakuan penggenangan disebabkan adanya sel penjaga. Ukuran sel penjaga setelah mengalami cekaman genangan akan mengecil sehingga kenampakan stomata yang terlihat akan lebih merapat dan lebih banyak namun dengan ukuran stomata yang lebih kecil. Kerapatan stomata merupakan upaya tanaman dalam merespon adanya cekaman genangan. Hal ini juga merupakan cara tanaman dalam beradaptasi dan memperbaiki kerusakan setelah tercekam genangan. Semua 


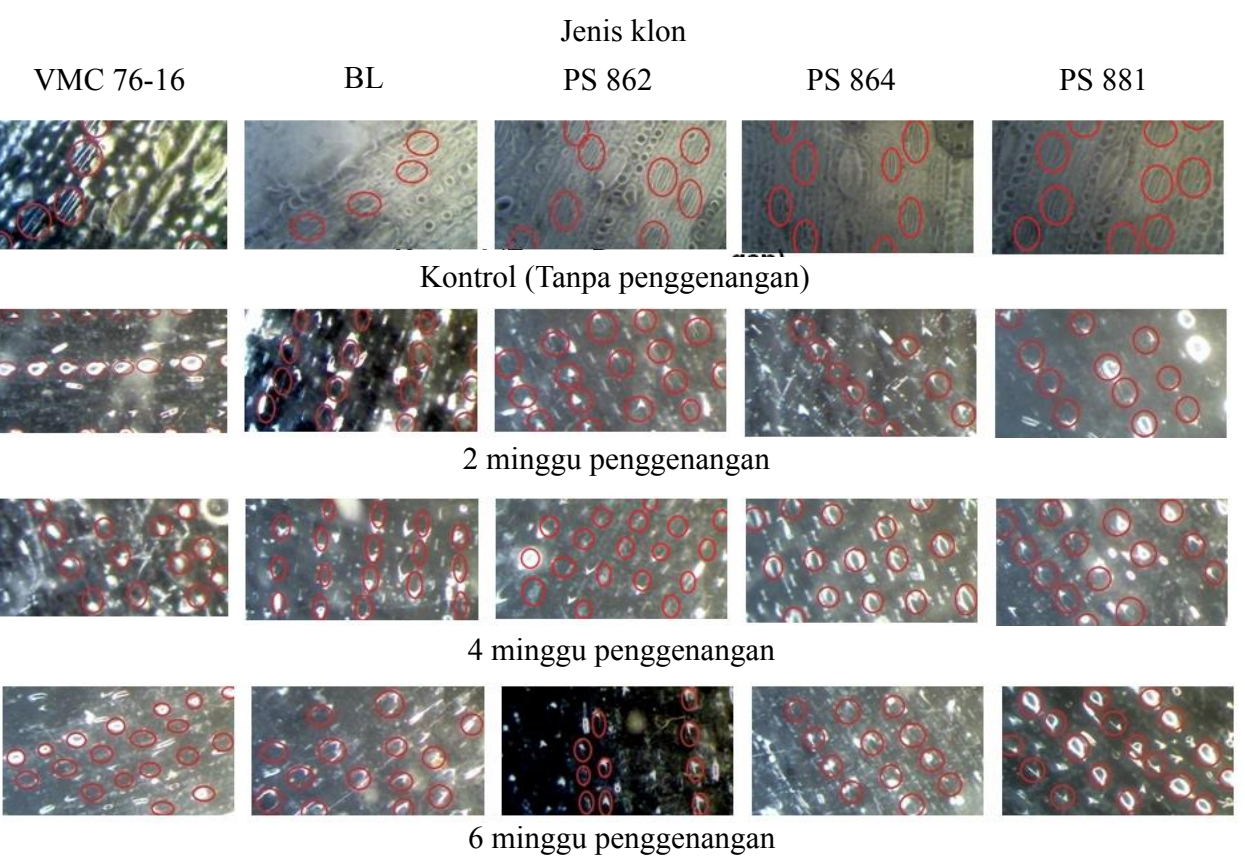

Gambar 8. Kerapatan stomata daun tebu sebelum dilakukan penggenangan dan setelah dilakukan penggenangan. Lingkaran menunjukkan letak stomata

varietas yang diuji mengalami pertambahan dalam kerapatan stomatanya setelah perlakuan penggenangan.

Adapun varietas yang dinilai mempunyai respon ketahanan yang lebih baik dari varietas-varietas yang lain adalah varietas VMC 76-16 dan varietas PS 881. Perbedaan respon toleransi terhadap genangan air dapat disebabkan oleh perbedaan varietas. Beberapa faktor abiotik seperti curah hujan, sinar matahari, suhu, jenis tanah, dan kondisi lain yang mempengaruhi pertumbuhan dan sifat tanaman terkadang dapat menunjukkan perbedaan respon yang cukup besar dari varietas yang berbeda (Thitisaksakul et al., 2012; Beckles and Thitisaksakul, 2014; Dalei et al., 2015).

Varietas VMC 76-16 dan PS 881 (Tabel 1) mempunyai pertumbuhan yang lebih baik dibandingkan dengan

Tabel 1. Jumlah akar adventif, kerapatan stomata dan jaringan aerenkim

\begin{tabular}{|c|c|c|c|c|c|}
\hline \multirow[b]{2}{*}{ Varietas } & \multicolumn{3}{|c|}{ Tanpa penggenangan } & \multicolumn{2}{|c|}{ Rendah (2 minggu penggenangan) } \\
\hline & Akar adventif $(\mathrm{g})$ & $\begin{array}{l}\text { Kerapatan stomata } \\
\left(\mathrm{mm}^{-2}\right)\end{array}$ & Jaringan aerenkim & Akar adventif (g) & $\begin{array}{c}\text { Kerapatan stomata } \\
\left(\mathrm{mm}^{-2}\right)\end{array}$ \\
\hline VMC 76-16 & 112.6 & 31.8 & Tidak ada & 167.7 & 62.2 \\
\hline $\mathrm{BL}$ & 86.0 & 26.0 & Tidak ada & 120.2 & 66.6 \\
\hline PS 862 & 78.9 & 39.1 & Tidak ada & 127.1 & 43.4 \\
\hline PS 864 & 66.2 & 43.4 & Tidak ada & 126.9 & 55.0 \\
\hline PS 881 & 79.9 & 30.4 & Tidak ada & 142.7 & 70.9 \\
\hline \multirow[b]{2}{*}{ Varietas } & \multicolumn{2}{|c|}{ Sedang (4 minggu penggenangan) } & \multicolumn{3}{|c|}{ Berat (6 minggu penggenangan) } \\
\hline & Akar adventif (g) & $\begin{array}{l}\text { Kerapatan stomata } \\
\qquad\left(\mathrm{mm}^{-2}\right)\end{array}$ & Akar adventif (g) & $\begin{array}{l}\text { Kerapatan stomata } \\
\qquad\left(\mathrm{mm}^{-2}\right)\end{array}$ & Jaringan aerenkim \\
\hline VMC 76-16 & 253.2 & 52.1 & 348.0 & 59.3 & Ada \\
\hline $\mathrm{BL}$ & 128.0 & 57.9 & 207.5 & 63.7 & Ada \\
\hline PS 862 & 151.1 & 65.1 & 213.9 & 65.1 & Ada \\
\hline PS 864 & 223.2 & 53.5 & 339.3 & 46.3 & Ada \\
\hline PS 881 & 256.3 & 66.6 & 429.2 & 82.5 & Ada \\
\hline
\end{tabular}

Keterangan: Jaringan aerenkim di uji pada tanaman yang tidak digenangi dan tanaman yang digenangi pada minggu ke- 6 setelah perlakuan penggenangan 
pertumbuhan varietas yang lain. Hal ini ditunjukkan pada beberapa parameter seperti parameter pertumbuhan akar adventive. Pada kedua varietas tersebut semakin lama penggenangan menyebabkan akar adventive semakin banyak. Akar adventif ini sangat membantu tanaman bertahan dan tumbuh dalam kondisi tergenang. Kedua varietas ini juga mempunyai berat kering akar yang lebih berat dibandingkan dengan varietas yang lain (Gambar 6). Varietas PS 881 juga mempunyai nilai kerapatan stomata paling tinggi dari varietas yang lain. Berdasarkan data visual Gambar 8 menunjukkan bahwa kerapatan stomata semakin rapat setelah dilakukan penggenangan dengan ukuran lebih kecil.

\section{KESIMPULAN}

Varietas VMC 76-16 dan PS 881 lebih toleran terhadap cekaman genangan dibandingkan varietas yang lainnya dilihat dari parameter tinggi tanaman, berat kering akar, jaringan aerenkim, dan kerapatan stomata. Varietas PS 862 paling peka terhadap kondisi genangan.

\section{UCAPAN TERIMA KASIH}

Terimakasih kepada Kementrian Riset, Teknologi, dan Pendidikan Tinggi, atas dana penelitian hibah tim pascasarjana dengan nomor kontrak 273/UN25.3.1/ LT6/2014. Terimakasih juga diucapkan kepada PG. Semboro atas bantuan varietas-varietas tebu yang digunakan dalam penelitian.

\section{DAFTAR PUSTAKA}

Ahmed, F., M.Y. Rafii, M.R. Ismail, A.S. Juraimi, H.A. Rahim, R. Asfaliza, M.A. Latif. 2013. Waterlogging tolerance of crops: Breeding, mechanism of tolerance, molecular approaches, and future prospects. BioMed Res. Internat. 2013:1-10. Doi:10.1155/2013/963525.

Avivi, S., S. Soeparjono, Slameto, R.A. Ramadhan. 2016. Physiological Characters of Sugarcane After Flooding Stress. Agriculture and Agricultural Science Procedia. 9:31-39. Doi:10.1016/j.aaspro.2016.02.119.

Beckles, D.M., M. Thitisaksakul. 2014. How environmental stress affects starch composition and functionality in cereal endosperm. Starch/Stärke. 66:58-71.

Dalei, L., C. Xuemei, S. Yaxing, Z. Jiuran, L. Weiping. 2015. Effects of waterlogging after pollination on the physicochemical properties of starch from waxy maize. Food Chem. 179:232-238.

Dawood, T., I. Rieu, M. Wolters-Arts, E.B. Derksen, C, Mariani, E.J.W. Visser. 2014. Rapid flooding-induced adventitious root development from preformed primordia in Solanum dulcamara. AoB PLANTS 6: plt058. Doi:10.1093/aobpla/plt058.

Direktorat Jenderal Perkebunan. 2014. Statistik Perkebunan Indonesia Komoditas Tebu 2013-2015. Direktorat Jenderal Perkebunan, Kementerian Pertanian Indonesia. Jakarta, Desember 2014.

Fan, Y., H. Chunyu, L. Zhen, G. Yangnan, C. Zhulong. 2015. Dissecting tissue and specific responses of two plantago species to waterlogging stress at physiological level. Environ. Exp. Bot. 109:177185.

Gilbert, R.A., C.R. Rainbolt, D.R. Morris, J.M. McCray. 2008. Sugarcane growth and yield responses to a 3month summer flood. Agric. Water Manag. 95:283291.

Haque, M.E., A. Fumitaka, M. Masahiko, O. Atsushi, K. Setsuko, K. Kentaro. 2014. Characterization of a wheat pathogenesis-related protein, TaBWPR-1.2, in seminal roots in response to waterlogging stress. J. Plant Physiol. 171:602-609.

Lee, Y.H., K.S. Kim, Y.S. Jang, J.H. Hwang, D.H. Lee, I.H. Choi. 2014. Global gene expression responses to waterlogging in leaves of rape seedlings. Plant Cell Rep. 33:289-99.

Mickelbart, M.V., P.M. Hasegawa, J. Bailey-Serres. 2015. Genetic mechanisms of abiotic stress tolerance that translate to crop yield stability. Nat Reviews Genet. 16:237-251. Doi:10.1038/nrg3901.

Parent, C., C. Nicolas, A.Berger, M. Crevecoeur, J.F. Dat. 2008. An overview of plant response to soil waterlogging. Plant Stress. 2:20-27.

Pezeshki, S.R., R.D. DeLaune. 2012. Soil oxidationreduction in wetlands and its impact on plant functioning. Biology (Basel). 1:196-221. Doi: 10.3390/biology1020196.

Pucciariello, C., P. Perata. 2013. Quiescence in rice submergence tolerance: An evolutionary hypothesis. Trends Plant Sci. 18:377-381.

Thitisaksakul, M., R. C. Jimenez, M. C. Abias, D. M. Beckles. 2012. Effects of environmental factors on cereal starch biosynthesis and composition. J. Cereal Sci. 56:67-80.

Verhoeven, J.T.A., T.L. Setter. 2010. Agricultural use of wetlands: opportunities and limitations. Ann Bot. 105:155-163. Doi:10.1093/aob/mcp172. 
Widyasari, W.B., Damanhuri, H. Budhisantoso. 2011. Respon 13 klon tebu introduksi asal Australia terhadap cekaman genangan. Majalah Penelitian Gula. 47:10-27.

Xiao-ming, W., T. Susan, H. Kerstin, S. Rainer. 2013. Changes in $\mathrm{Sb}$ specification with waterlogging of shooting range soils and impacts on plant uptake. Environ. Pollution. 172:53-60.
Yullianida, Suwarno, S.W. Ardie, H. Aswidinnoor. 2014. Uji cepat toleransi tanaman padi terhadap cekaman rendaman pada fase vegetatif. J. Agron. Indonesia 42:89-95.

Zhao, D., Y.R. Li. 2015. Climate change and sugarcane production: Potential impact and mitigation strategies. Internat. J. Agron. 2015:1-10. Doi:10.1155/2015/547386. 